\title{
Availability and Utilization of Vocational Guidance and Counselling Services in Technical Colleges in Taraba State
}

\author{
M. A. Auta ${ }^{1 *}$, F. U. Udeagha ${ }^{2}$, F. N. Chibuzo ${ }^{1} \&$ M. Giwa ${ }^{3}$ \\ ${ }^{1}$ Department of Technology and Vocational Education, Nnamdi Azikiwe University, Awka, Nigeria \\ ${ }^{2}$ Department of Guidance and Counselling, Nnamdi Azikiwe University, Awka, Nigeria \\ ${ }^{3}$ Department of Building Technology, Federal College of Education (Technical), Asaba, Nigeria
}

DOI: $\underline{10.36348 / \text { sb.2019.v05i12.020 }}$ | Received: 05.12.2019| Accepted: 12.12.2019| Published: 30.12 .2019

*Corresponding author: M. A. Auta

\section{Abstract}

The purpose of the study was to determine the availability and utilization of vocational and guidance counselling services in technical colleges in Taraba State. The study adopted descriptive research design. The area of the study was Taraba state, located in north-eastern part of Nigeria. The population of the study comprises of 743 final year students in the eight technical colleges in the state. The sample size for the study was 223 which represent $30 \%$ of the population. Observation checklist and questionnaire were used as an instrument for data collection. The instrument was validated by five experts, three from the department of guidance and counselling and two from the department of technology and vocational education in Nnamdi Azikiwe University, Awka. The questionnaire was trial tested on 20 teachers at Government Technical College Numan, Adamawa state; Cronbach alpha was used to analyze the data generated from the trial and a reliability coefficient of 0.84 was obtained. Frequency count and percentage and percentage were used to analyze data to answer research question one and two. Mean was used to analyze data to answer research question three. Findings from the study indicated that in Technical colleges in Taraba state, there is only one Vocational guidance and counsellor, nine Para-counsellors, and one support staff; there are 10 vocational guidance and counselling services available; and only four vocational guidance services are utilized. It is recommended that technical college proprietors in the state should hire and post more vocational guidance and counsellors for their respective schools and technical college managers should ensure that more vocational guidance and counselling services are initiated and made available to students.

Keywords: Availability, Utilization, Vocational, Guidance, Counselling, Services, Technical, Colleges.

Copyright @ 2019: This is an open-access article distributed under the terms of the Creative Commons Attribution license which permits unrestricted use, distribution, and reproduction in any medium for non-commercial use (NonCommercial, or CC-BY-NC) provided the original author and source are credited.

\section{INTRODUCTION}

Technical colleges are post-basic education institutions established to train and equip students with appropriate skills, knowledge and aptitude to enable them function as craftsmen/Master Craftsmen in the industry. This type of institution is owned either by government or other private organizations and the responsibility for supervision of the programme is vested with the National Board for Technical Education (NBTE). At the end of the programmes, the graduates are expected to secure jobs in the industry either as selfemployed or paid-employees. The programme usually last for three years and a National Technical Certificate (NTC) is awarded to the deserving graduates by the National Business and Technical Examination Board (NABTEB) (National Board for Technical Education
[NBTE], 2018) [1]. For those who may wish to go a bit further to earn a Master Craftsmen Certification, a one year Advanced national technical certificate (ANTC) programme is also available in some few selected technical colleges. There are several trades available in technical colleges; these include carpentry and joinery, furniture making and upholstery, plumbing and pipe fittings, motor vehicle mechanic work among others. A prospective candidate is therefore at liberty to make a choice from this range of vocations.

Vocational choice, just like the choice of marriage partner is very important decision that every individual has to make; when this decision is done rightly, it has the potential to guarantee blissful future. In a technical college, the choice of a vocation or trade to pursue is a task that must be handled with all the 
necessary care it deserves. Bobga [2] observed that, selecting a trade out of the many available ones is becoming more complex, this is due to the inability of individuals especially the junior secondary school leavers to keep their choices more flexible, this is in addition to the high level of vocational aspiration they set for themselves without evaluating the qualities needed to pursue them. One of the several mediums to assist these young people is through the vocational guidance and counselling services.

Vocational guidance and counselling services are those professional help offered mostly in schools to assist students in making a right and informed decision regarding vocational choices. The objective is to assist an individual to be able to pin-point their aptitude, skills and talent which will help them to be able to decide which vocation to go into. As human beings differ, so vocation differs, and each has specific traits needed; and what vocational counselor does is to match the client's aptitude with the requirements of the vocation under consideration in order to make an intelligent decision which can lead to job satisfaction and fulfillment [2]. These vocational guidance and counselling services can take the shape of personal counselling, excursion, keeping and updating cumulative record cards, vocational rehabilitation, career exhibition, vocational library services among others.

Unfortunately, the authors observed that despite the positive role plays by vocational guidance and counselling services in schools, technical college students in Taraba state appears not to be benefiting from these vital services. However, it appears that there is no empirical evidence to prove if these services are actually available and are being utilized. This reason birthed this study to determine the availability and utilization of vocational counselling Services in Technical Colleges in Taraba State

\section{Purpose of the Study}

The study sought to determine the

1. Level of availability of vocational guidance and counselling personnel in Technical colleges in Taraba State.

2. The level of availability of vocational guidance and counselling services in Technical colleges in Taraba state.

3. The level of utilization of vocational guidance and counselling services in Technical colleges in Taraba state

\section{Research Questions}

The study answered the following questions:

1. What is the level of availability of vocational guidance and counselling personnel in Technical colleges in Taraba State?

2. What is the level of availability of vocational guidance and counselling services in Technical colleges in Taraba state?

3. What is the level of utilization of vocational guidance and counselling services in Technical colleges in Taraba state

\section{METHOD}

The study adopted descriptive research design. The area of the study was Taraba state, located in northeastern part of Nigeria. The population of the study comprises of 743 final year students in the eight technical colleges in the state. The sample size for the study was 223 which represent $30 \%$ of the population. Observation checklist and questionnaire were used as an instrument for data collection. The instrument was validated by five experts, three from the department of guidance and counselling and two from the department of technology and vocational education in Nnamdi Azikiwe University, Awka. The questionnaire was trial tested on 20 teachers at Government Technical College Numan, Adamawa state; Cronbach alpha was used to analyze the data generated from the trial and a reliability coefficient of 0.84 was obtained. Frequency count and percentage and percentage were used to analyze data to answer research question one and two. Mean was used to analyze data to answer research question three in accordance with the real limit of numbers presented below:

\begin{tabular}{|l|l|l|l|l|}
\hline Response & Point & Lower Limit & & Upper Limit \\
\hline Very High & 5 & 4.50 & - & 5.00 \\
\hline High & 4 & 3.50 & - & 4.49 \\
\hline Moderately High & 3 & 2.50 & - & 3.49 \\
\hline Low & 2 & 1.50 & - & 2.49 \\
\hline Very Low & 1 & 1 & - & 1.49 \\
\hline
\end{tabular}

\section{RESULTS}

\section{Research Question 1} Taraba State?

What is the level of availability of vocational guidance and counselling personnel in Technical colleges in 
M. A. Auta et al., Sch Bull, Dec 2019; 5(12): 834-838

Table-1: Level of Availability of Vocational Guidance and Counselling Personnel in Technical Colleges in Taraba State

\begin{tabular}{|l|l|l|l|l|l|}
\hline S/N & Technical Colleges & Counsellors & Para-Counsellors & Support Staff & Total \\
\hline 1 & FSTC, Jalingo & 1 & 2 & 1 & 4 \\
\hline 2 & GTTS, Jalingo & 0 & 2 & 0 & 2 \\
\hline 3 & GTTS, Bali & 0 & 1 & 0 & 1 \\
\hline 4 & GTTS, Karim-Lamido & 0 & 0 & 0 & 0 \\
\hline 5 & GTTS, Gembu & 0 & 2 & 0 & 2 \\
\hline 6 & GTTS, Wukari & 0 & 1 & 0 & 1 \\
\hline 7 & GTTS, Takum & 0 & 1 & 0 & 1 \\
\hline 8 & GTTS, Zing & 0 & 0 & 0 & 0 \\
\hline & Total & 1 & 9 & 1 & 11 \\
\hline
\end{tabular}

Table-2: Percentage of Level of Availability of Vocational Guidance and Counselling Personnel in Technical

Colleges in Taraba State

\begin{tabular}{|l|l|l|l|}
\hline S/N & Category of Personnel & Frequency Count & Percentage \\
\hline 1 & Counsellors & 1 & 9.09 \\
\hline 2 & Para-Counsellors & 9 & 81.82 \\
\hline 3 & Support Staff & 1 & 9.09 \\
\hline & Total & 11 & 100 \\
\hline
\end{tabular}

The data presented in Table-2 indicated that there were only 11 Guidance and counselling personnel available in all the technical colleges in the state. As shown in Table-2, out of these numbers, one was a Professional counsellor, nine were Para-counsellors and only one support staff; this represents 9.09, 81.82, and 9.09 percent respectively.

\section{Research Question 2}

What is the level of availability of vocational guidance and counselling services in Technical colleges in Taraba State?

Table-3: Level of Availability of Vocational Guidance and Counselling Services in Technical Colleges in Taraba State

\begin{tabular}{|l|l|l|l|l|}
\hline S/N & Vocational Counselling Services & N & Frequency & Percentage \\
\hline 1 & Career Talk & 8 & 2 & 25 \\
\hline 2 & Excursion & 8 & 4 & 50 \\
\hline 3 & Individual and Group Vocational Counselling & 8 & 7 & 87.5 \\
\hline 4 & Referral services & 8 & 7 & 87.5 \\
\hline 5 & Enhancing parent skills on vocational programmes & 8 & 0 & 0 \\
\hline 6 & $\begin{array}{l}\text { Contacting parents regarding students' vocational choices and } \\
\text { other specific problems }\end{array}$ & 8 & 1 & 12.5 \\
\hline 7 & Keeping and updating students' cumulative record cards & 8 & 0 & 0 \\
\hline 8 & Vocational rehabilitation services & 8 & 0 & 0 \\
\hline 9 & Career exhibition & 8 & 3 & 37.5 \\
\hline 10 & Orientation & 8 & 1 & 12.5 \\
\hline 11 & Career clubs & 8 & 1 & 12.5 \\
\hline 12 & Role playing & 8 & 0 & 0 \\
\hline 13 & Remedial laboratory services & 8 & 0 & 0 \\
\hline 14 & Consultancy services & 8 & 0 & 0 \\
\hline 15 & Testing services & 8 & 0 & 0 \\
\hline 16 & Motivational services & 8 & 1 & 12.5 \\
\hline 17 & Vocational library services & 8 & 1 & 12.5 \\
\hline
\end{tabular}

Data for answering research question 2 is presented in Table 3; the data indicated that out of the 17 vocational guidance and counselling services presented, only 10 are available and in varying degrees. The level of availability of these services ranges from $12.5-87.5 \%$ with two vocational and counselling services scoring the highest and five others scoring the lowest. The data also shows that six other services are not existent in the technical colleges under study.

\section{Research Question 3}

What is the level of utilization of vocational guidance and counselling services in Technical colleges in Taraba State? 
M. A. Auta et al., Sch Bull, Dec 2019; 5(12): 834-838

Table 4: Level of Utilization of Vocational Guidance and Counselling Services in Technical Colleges in Taraba State

\begin{tabular}{|l|l|l|l|}
\hline S/N & Vocational Counselling Services & Mean & Remarks \\
\hline 1 & Career Talk & 1.86 & Low \\
\hline 2 & Excursion & 2.63 & Moderately High \\
\hline 3 & Individual and Group Vocational Counselling & 4.23 & High \\
\hline 4 & Referral services & 4.01 & High \\
\hline 5 & Enhancing parent skills on vocational programmes & 1.23 & Very Low \\
\hline 6 & $\begin{array}{l}\text { Contacting parents regarding students' vocational choices and other } \\
\text { specific problems }\end{array}$ & 1.39 & Very Low \\
\hline 7 & Keeping and updating students' cumulative record cards & 1.02 & Very Low \\
\hline 8 & Vocational rehabilitation services & 1.33 & Very Low \\
\hline 9 & Career exhibition & 2.57 & Moderately High \\
\hline 10 & Orientation & 1.67 & Low \\
\hline 11 & Career clubs & 2.05 & Low \\
\hline 12 & Role playing & 1.26 & Very Low \\
\hline 13 & Remedial laboratory services & 1.08 & Very Low \\
\hline 14 & Consultancy services & 1.32 & Very Low \\
\hline 15 & Testing services & 1.29 & Very Low \\
\hline 16 & Motivational services & 1.39 & Very Low \\
\hline 17 & Vocational library services & 1.41 & Very Low \\
\hline
\end{tabular}

The data obtained for answering research question 3 is presented in Table-4. The data indicated that the 17 items presented have mean value ranging from 1.02 to 4.23 . Two services fell under the category of highly utilized, and another two services were considered by the respondents as moderately utilized. Three and 10 services were rated as lowly and very lowly utilized by the respondents respectively.

\section{Findings of the Study}

The following are the findings of the study;

- There is only one Vocational guidance and counsellor, nine Para-counsellors, and one support staff in Technical colleges in Taraba state.

- There are 10 vocational guidance and counselling services available in technical colleges in Taraba state.

- Only four vocational guidance services are utilized in Technical colleges in Taraba state.

\section{DISCUSSION OF FINDINGS}

Findings from the study indicated that there is only one Vocational guidance and counsellor, nine Para-counsellors, and one support staff in Technical colleges in Taraba state. This finding is consistent with that of Egbo [3] who discovered that there is paucity of professional counsellors in Nigerian secondary schools; this inadequacy has brought about serious challenge for students particularly in making decisions that may have far reaching consequences on their career and well being. This problem according to the author, led to most students completing their secondary education ignorant of the existence of guidance and counselling services in their respective schools.
The study also discovered that, individual and group counselling, referral services, excursion, career exhibition are some of the vocational guidance and counselling services available in the schools. Other important services such as keeping and updating students' cumulative record cards, vocational rehabilitation services are complete absence in the schools vocational guidance and counselling services. This finding is in agreement with Agbaje and Agbaje [4] who had earlier observed that, lack of proper students' records as well as well as other vital information are some of the challenges confronting vocational guidance services in schools. These problems rendered the vocational guidance and counsellor handicapped on how to render an informed and intelligent advice to students on their vocational and career aspiration.

Findings from the study also indicated that excursion, individual and group counselling, referral services and career exhibition are the vocational guidance and counselling services utilized in the schools. This finding is in line with Ultanir [5] and Egbo [3] who discovered that most of the vocational counselling services are not available in secondary schools; this have become an impediment to the realization of the goals of school guidance and counselling services which has led to several mismatch between the students aptitude and the chosen course of study.

\section{CONCLUSION}

The paper appraised the availability and utilization of vocational guidance and counselling services in technical college in Taraba state; findings indicated that most of these vocational guidance and 
counselling services are not available, accordingly, only the few available services are utilized. It is expected that when vocational guidance and counselling services are made available and utilized, it will go a long way in reshaping the vocational aspiration and career choices of technical college students for prosperous studies and improved productivity in the field of work.

\section{RECOMMENDATIONS}

It is recommended that;

- Technical college proprietors in the state should hire and post more vocational guidance and counsellors for their respective schools.

- Technical college managers should ensure that more vocational guidance and counselling services are initiated and made available to students.

\section{REFERENCES}

1. National Board for Technical Education. (2018). Curriculum for carpentry and joinery. Kaduna: NBTE Press
2. Bodga, T. J. (2016). An appraisal of effective provision of guidance and counselling services in Cameroon state universities: Trends and challenges. International Journal of Humanities Social Science and Education. 3(9):75-90.

3. Egbo, A. C. (2015). The challenges of guidance and counselling practice as perceived by secondary school counsellors in Enugu state Nigeria. International Journal of Education and Research. 3(5):375-384.

4. Agbaje, A. A., \& Agbaje, A. O. (2014). Understanding problems of vocational counselling information seeking behaviour in the modern Nigeria. IOASR Journal of Humanities and Social Science. 19(5):50-57.

5. Ultanir, E. (2012). The factors affecting career guidance and current status of career guidance services in Turkey. Problems of Education in the $21^{\text {st }}$ Century. 48(1):135-144. 